\title{
Enzymatic synthesis of DNA employing pyrophosphate-linked dinucleotide substrates
}

\author{
Xiao-Ping Song, Mohitosh Maiti and Piet Herdewijn ${ }^{*}$
}

\begin{abstract}
Background: One of the remaining questions in the understanding of the origin of Nature's information system is the way the first nucleic acids have been synthesized. This could have been realized using nucleoside triphosphates or imidazolides of nucleoside monophosphates as building blocks. Alternatively, dinucleoside pyrophosphates could have been used for this purpose. The advantage of using building blocks, composed of pyrophosphate-linked dinucleotides, could be that exponential growth of initial information (dinucleotides) without product inhibition might become possible.

Results: Herein, we demonstrate that dinucleoside pyrophosphates are able to act as substrate for HIV-1 RT and several thermostable DNA polymerases. In single incorporation assay, compound dAppdA was able to give a 100\% conversion to the $(\mathrm{P}+1)$ strand by Therminator DNA polymerase and at a substrate concentration above $100 \mu \mathrm{M}$. Fulllength elongation was obtained in a chain elongation experiment, with over $95 \%$ yield of $(\mathrm{P}+7)$ product by Taq and Vent (exo) DNA polymerase. Interestingly, using heterodimer dAppdT addition of either nucleotide component of the dinucleotide substrate into the DNA chain can occur, which is defined by the template program.

Conclusions: This study shows that dinucleoside pyrophosphates can be considered as a new type of substrate for polymerases in the template-directed DNA synthesis. Using heterodimers as substrate, theoretically, it is possible to synthesize DNA enzymatically using two building blocks (dAppdT and dGppdC) instead of four. Given the poor Km value for the nucleotide incorporation, evolution of polymerases will become necessary to make this process of practical use.
\end{abstract}

\section{Background}

The phosphorylation of nucleosides and nucleoside monophosphates under prebiotic conditions and leading to the formation of nucleoside diphosphates and nucleoside triphosphates was studied in the seventies of the previous century [1-5]. These studies were performed based on the observation that four nucleoside triphosphates are used as building blocks for the synthesis of each natural information system (DNA and RNA). In the context of the question "why this and not that", it is not unreasonable to ask the question why Nature uses four reagents to synthesize information systems and not two, composed of, for example, dinucleoside pyrophosphates. Dinucleoside pyrophosphates are not alien to cellular biology, demonstrated by the coenzyme function of $\mathrm{NAD}^{+}$(Figure 1) and $\mathrm{NADP}^{+}$in redox reactions. Moreover, $\mathrm{NAD}^{+}$is used by poly(ADP-

\footnotetext{
* Correspondence: Piet.Herdewijn@rega.kuleuven.be Rega Institute for Medical Research, Laboratory of Medicinal Chemistry, Katholieke Universiteit Leuven, Minderbroedersstraat 10, 3000 Leuven, Belgium
}

(C) 2011 Song et al; licensee Chemistry Central Ltd. This is an Open Access article distributed under the terms of the Creative Commons Attribution License (http://creativecommons.org/licenses/by/2.0), which permits unrestricted use, distribution, and reproduction in any medium, provided the original work is properly cited. ribose) polymerase to synthesize PAR (Poly ADP ribose) [6] polymers using nicotinamide as leaving group. The linking group between the ribosylated adenine and nicotinamide units is pyrophosphate. Another example is that of the ligases. Phosphodiester bond formation between a 3'hydroxyl group and a 5'-phosphoryl group in nicked DNA by ligase is running via the formation of a nucleotide pyrophosphate intermediate [7].

Dinucleotides are chemically easily available, demonstrated by the observation that the reaction of ImpA with glycolic acid in the presence of divalent metal ions may lead to AppA formation [8]. We also observed that LAsp-dTMP may dimerize in solution to give dTppdT (unpublished results). The use of pyrophosphate linked nucleotides as building blocks for nucleic acid synthesis has not been investigated so far.

Indeed, dNTPs, consisting of dATP, dCTP, dGTP and dTTP, are standard natural substrates of all DNA polymerases. The four dNTPs are used according to the base pairing rules to extend the primer. In the process 


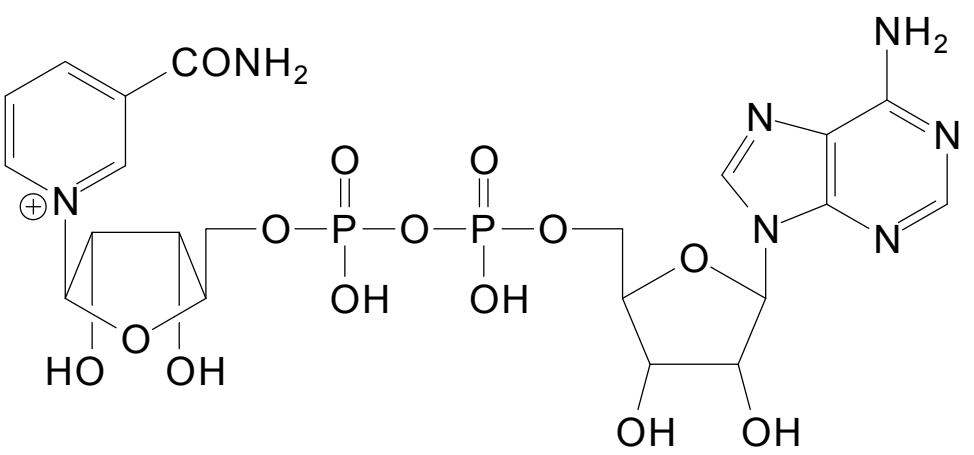

Figure 1 Structure of $\mathrm{NAD}^{+}$

of this polymerization, the enzyme catalyzes the phosphoester bond formation between the 3'-hydroxyl group of the primer and dNTP $\alpha$-phosphate, and makes a step along the $5^{\prime} \rightarrow 3$ ' direction while releasing a pyrophosphate molecule (PPi) as leaving group. In recent years, our group proved that some selected structures like amino acid phosphoramidates are able to be processed as substrates by polymerase in the enzymatic-catalyzed DNA synthesis [9-16], despite the fact that a P-N bond is much more stable than a P-O bond. For example, in a primer-template assay iminodipropionic acid-dAMP phosphoramidate (IDP-dAMP) is able to give a $91 \%$ conversion to the $(\mathrm{P}+1)$ strand at $50 \mu \mathrm{M}$ by HIV-1 RT [16]. In this case, the pyrophosphate leaving group (PPi) is replaced by an iminodipropionic acid group, which shows similar binding behaviours to the primer-template duplex and enzyme as pyrophosphate. This work is now extended by the demonstration that dinucleoside pyrophosphates (Table 1) are able to act as a new type of substrate by polymerase in the template-directed DNA synthesis, and this observation is relevant to the question about the origin of life of the present natural information system. The substrate properties towards various polymerases, as well as the stability study are discussed.

\section{Results and Discussion}

\section{Synthesis of dinucleoside diphosphates}

The synthesis of dinucleoside pyrophosphates I-VII was carried out using the corresponding nucleoside-5'- phosphorimidazolide as intermediates. Deoxynucleoside monophosphate was first converted to its phosphorimidazolide according to method described by Orgel and colleagues [17], then the phosphorimidazolide is reacted with the corresponding nucleoside monophosphate in $0.2 \mathrm{M}$ N-ethylmorpholine buffer $(\mathrm{pH}=8 \sim 8.5)$, using $\mathrm{Pd}\left(\mathrm{NO}_{3}\right)_{2}$ or $\mathrm{ZnCl}_{2}$ as catalyst (Scheme 1). After completion, appropriate amount of EDTA $(0.25 \mathrm{M})$ solution was added to disassociate the nucleotide-metal complex, followed by purification with HPLC (reverse phase C18 column) to provide the pure dinucleoside pyrophosphates.

\section{Single nucleotide incorporation by HIV-1 RT}

The substrate properties of compound I-VII catalyzed by HIV-1 RT, Taq, Vent (exo-) and Therminator DNA polymerase were studied using the primer-template complexes as shown in Table 2.

Since HIV-1 RT is an error-prone polymerase with high mutation rate, it exhibits flexibility and high tolerance towards chemically modified nucleotide substrate $[18,19]$. Therefore, we firstly select HIV-1 RT to perform the single nucleotide incorporation experiments in a primer-template assay. The building blocks were incubated at $37^{\circ} \mathrm{C}$, with the appropriate primer-template complex and $0.025 \mathrm{U} / \mu \mathrm{L}$ of enzyme, samples were taken after 10 , $20,30,60$, and $120 \mathrm{~min}$, and analyzed by polyacrylamide gel electrophoresis.

As shown in Figure 2a and 2b, compound $\mathbf{I}$ and $\mathbf{I I}$ can be recognized smoothly by HIV-1 RT, and incorporated

Table 1 Overview of the dinucleoside pyrophosphates used in this study.

\begin{tabular}{ccccc}
\hline Compound No. & Structure & Yield, $\%$ & ${ }^{31}$ P NMR, ppm & RT(HPLC), min \\
\hline I & dAppdA & 28 & -11.27 & 24 \\
II & dTppdT & 35 & -11.62 & 22 \\
III & dAppdT & 18 & -11.41 & 24 \\
IV & dGppdG & 33 & -11.33 & 23 \\
V & dGppdC & 15 & -11.40 & 22 \\
VI & dAppdC & 18 & -11.34 & 22 \\
VII & dCppdC & 26 & -8.84 & 20 \\
\hline
\end{tabular}




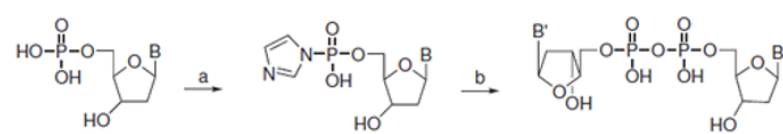

Scheme 1 Synthesis of compound I-VII. Reagents and conditions. (a) $\mathrm{Ph}_{3} \mathrm{P}$, imidazole, dipyridyl disulfide, DMSO, rt.; (b) dNMP ( $\mathrm{N}=\mathrm{A}$, $\mathrm{T}, \mathrm{G}, \mathrm{C}), 0.25 \mathrm{M}$ N-ethylmorpholine buffer $(\mathrm{pH}=8 \sim 8.5), \mathrm{Pd}\left(\mathrm{NO}_{3}\right)_{2} /$ $\mathrm{ZnCl}_{2}$, rt.

into the growing DNA stand resulting 100\% and 96\% conversion to the $(\mathrm{P}+1)$ strand at a concentration of 500 $\mu \mathrm{M}$ over a period of $2 \mathrm{~h}$, respectively. Interestingly, using compound III as reagent, containing a deoxyadenylate and a thymidylate residue, addition of either nucleotide component of the dinucleotide substrate can occur by HIV-1 RT, which is defined by the template program. As shown in Figure 2c and 2d, compound III is able to insert a deoxyadenylate residue into the $\mathrm{P}_{1} \mathrm{~T}_{1}$ with $48 \%$ conversion to the $(\mathrm{P}+1)$ strand (Figure $2 \mathrm{c}$ ), and also compound III is able to insert a deoxythymidylate residue into $\mathrm{P}_{1} \mathrm{~T}_{2}$ duplex with $32 \%$ conversion to the $(\mathrm{P}+1)$ strand (Figure $2 \mathrm{~d}$ ). Although the incorporation of compound III only gave us a moderate yield, it is interesting to observe that two different nucleotide residues (deoxyadenylate and deoxythymidylate) are able to be incorporated into the growing strand by a single molecule dinucleoside pyrophosphates instead of two classic dNTP building blocks. Based on the these observations, it is not unreasonable to hypothesize that it should be possible to replace the standard four dNTP building blocks with two dinucleoside pyrophosphate analogues in the enzymatic DNA polymerization reaction (e.g. PCR).

Compound IV with two deoxyguanylate residues demonstrates weaker substrate property to HIV-1 RT than the deoxyadenosine or deoxythymidine congeners, $43 \%$ conversion to the $(\mathrm{P}+1)$ strand was observed (Figure 3a). It is worthy mentioning that compound $\mathbf{V}$ and VI can be accepted as substrate by HIV-1 RT extending the primer with deoxyguanylate or deoxyadenylate

Table 2 Overview of primer and template sequences used in the DNA polymerase reaction ${ }^{[a]}$

\begin{tabular}{cl}
\hline Primer $P_{1}$ & 5'-CAGGAAACAGCTATGAC-3' $^{\prime}$ \\
\hline Primer $P_{2}$ & 5'-CAGGAAACAGCTATGACTGA-3' \\
\hline Template $T_{1}$ & 3'-GTCCTTTGTCGATACTGTCCC-5' \\
\hline Template $T_{2}$ & 3'-GTCCTTTGTCGATACTGACTGC-5' \\
\hline Template $T_{3}$ & 3'-GTCCTTTGTCGATACTGTTTTTTTGGAC-5' \\
\hline Template $T_{4}$ & 3'-GTCCTTTGTCGATACTGCTTTT-5' \\
\hline Template $T_{5}$ & 3'-GTCCTTTGTCGATACTGACTGAAAAA-5' \\
\hline Template $T_{6}$ & 3'-GTCCTTTGTCGTACTGTATATACGAT-5'
\end{tabular}

${ }^{[a]}$ Boldface letters indicate the template overhang in the hybridized primertemplate duplex. residue, although not very efficient (28\% conversion for compound V, 15\% conversion for compound VI) (Figure $3 \mathrm{~b}, \mathrm{c})$. Disappointingly, when trying to extend the primer with deoxycytidylate residue (compound V, VI VII) under the same conditions, no incorporation was detected (data not shown).

\section{Single nucleotide incorporation by other DNA polymerases}

After obtaining the single nucleotide incorporation results of compound I-VII with HIV-1 RT, we tested the single incorporation properties of compound I-VII with a selection of thermostable DNA polymerases.

Compound I demonstrates very good substrate properties towards Taq, Vent (exo-), or Therminator DNA polymerase. As shown in Figure 4, compound I can obtain 87\% conversion with Taq DNA polymerase (Figure 4a) and $100 \%$ primer extension with Vent (exo-) DNA polymerase at $500 \mu \mathrm{M}$ substrate concentration (Figure $4 \mathrm{~b}$ ). Remarkably, a maximal primer extension was observed by using Therminator DNA polymerase with substrate concentration above $100 \mu \mathrm{M}$ (Figure 4c).

Compound II, which shows similar substrate property as compound I using HIV-1 RT as polymerase, can achieve $70 \%$ conversion to $(\mathrm{P}+1)$ strand at $500 \mu \mathrm{M}$ substrate concentration in $60 \mathrm{~min}$ and $100 \%$ conversion at $1 \mathrm{mM}$ by Therminator DNA polymerase (Figure 4d). However, compound II was not a substrate for Taq and Vent (exo-) DNA polymerase, as no $(\mathrm{P}+1)$ product formation was observed at the concentrations ranging from $100 \mu \mathrm{M}$ to $1 \mathrm{mM}$ (data not shown).

We also evaluated the substrate properties of compound III-VII for Taq, Vent (exo-) and Therminator DNA polymerase. Unfortunately, Taq and Vent (exo') DNA polymerase failed to incorporate compound III-VII into a growing primer strand (Table 3). After $2 \mathrm{~h}$ of polymerase reaction, no $(\mathrm{P}+1)$ product was observed at $1 \mathrm{mM}$ substrate concentration (Table 3).

Therminator is a mutant variant of the $9^{\circ} \mathrm{N}$ exo $0^{-}$polymerase (Thermococcus species $9^{\circ} \mathrm{N}-7$ ), in which the Ala 485 residue has been replaced with Leu residue. This enzyme demonstrated effective ability of recognition and incorporation of a number of modified nucleotides bearing unnatural nucleobase and sugar moieties [20]. Using compound III-VI as substrates, Therminator polymerase was able to insert deoxyadenylate, deoxythymidylate and deoxyguanylate residue into the DNA primer-template complex (Table 3 ) depending on the template program, however, it fails to incorporated the deoxycytidylate residue into the growing primer strand as observed for HIV$1 \mathrm{RT}$. The observed diversity in incorporation selectivity for various polymerases (HIV-1 RT, Taq, Vent (exo-)) indicates the differences in tolerance of the active site of polymerase to the triphosphate modifications. 


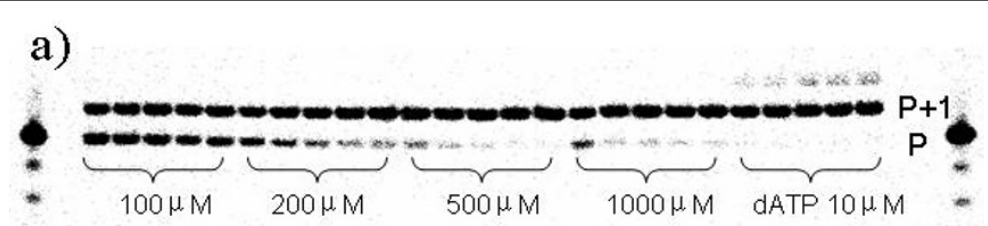

b)

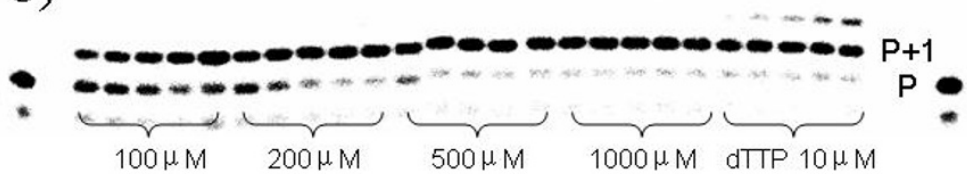

c)

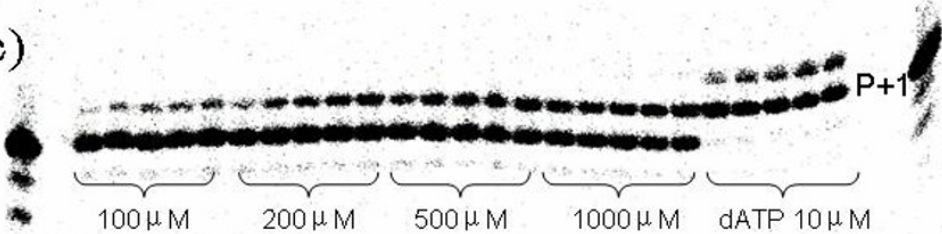

d)

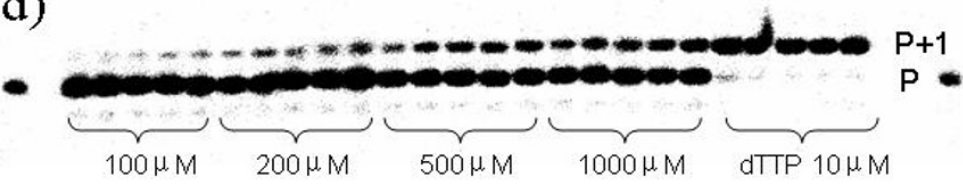

Figure 2 Single incorporation of compound I, II, and III by HIV-1 RT. [HIV-1 RT] = $0.025 \mathrm{U} / \mu \mathrm{L}$, time points: 10, 20, 30, 60, and 120 min. a) Incorporation of compound I, $\left[\mathrm{P}_{1} T_{1}\right]=125 \mathrm{nM} ; \mathrm{b}$ ) Incorporation of compound II, $\left[\mathrm{P}_{1} \mathrm{~T}_{2}\right]=125 \mathrm{nM} ; \mathrm{c}$ ) Incorporation of compound III, $\left[\mathrm{P}_{1} T_{1}\right]=125$ $\mathrm{nM}$; d) Incorporation of compound III, $\left[\mathrm{P}_{1} \mathrm{~T}_{2}\right]=125 \mathrm{nM}$.

Primer extension experiments

So far, compound I show the best results in single nucleotide incorporation experiments towards various polymerases. We decided to further investigate the chain elongation property of compound I by HIV-1 RT,
Taq, Vent (exo') and Therminator DNA polymerase, respectively. In this experiment a template overhang with seven thymidines and flanked by four non-thymidine nucleotides at the 3 '-end was used. The building block was incubated at the appropriate temperature in a

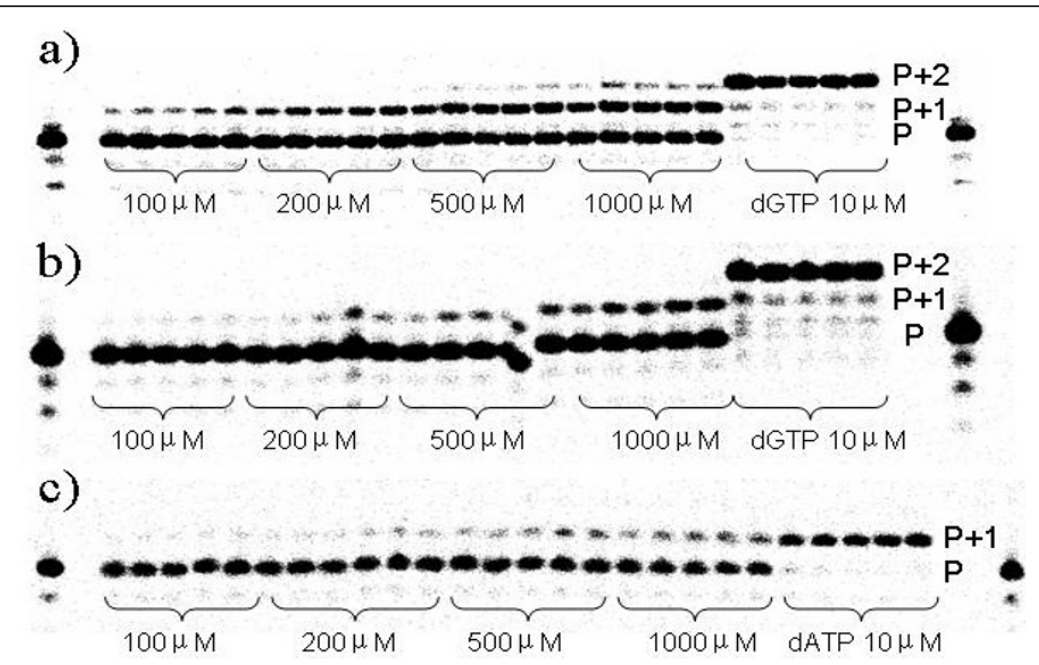

Figure 3 Single incorporation of compound IV, V and VI by HIV-1 RT. [HIV-1 RT] = 0.025 U/ML, time points: 10, 20, 30, 60, and 120 min. a) Incorporation of compound IV, $\left[P_{1} T_{4}\right]=125 \mathrm{nM}$; b) Incorporation of compound $\left.V_{,}\left[P_{1} T_{4}\right]=125 \mathrm{nM} ; c\right)$ Incorporation of compound $V \mid,\left[P_{1} T_{1}\right]=$ $125 \mathrm{nM}$. 


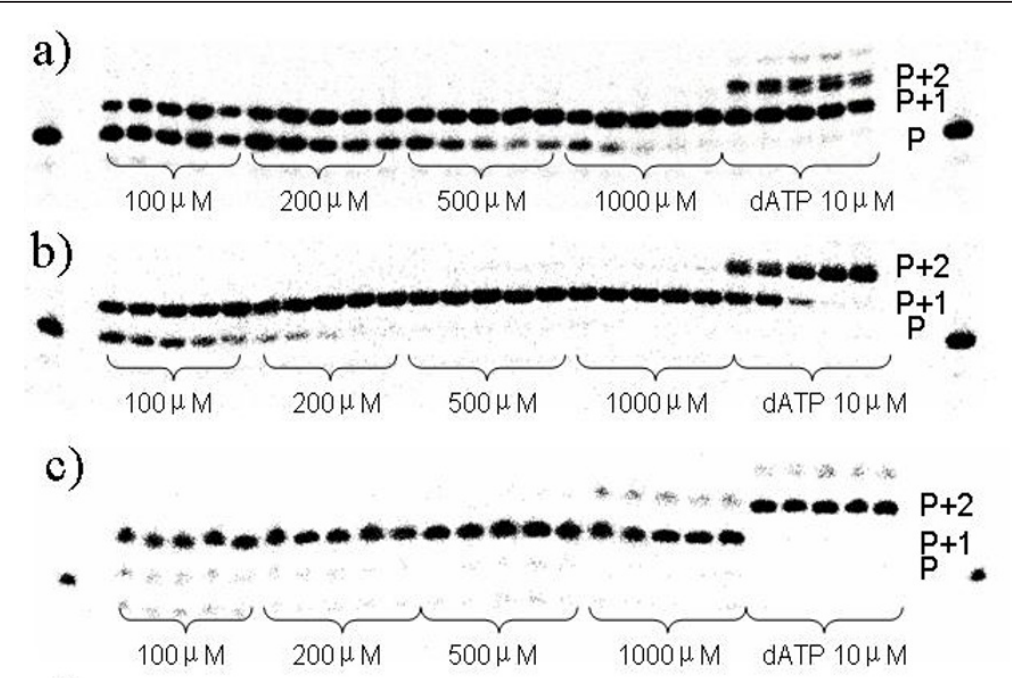

d)

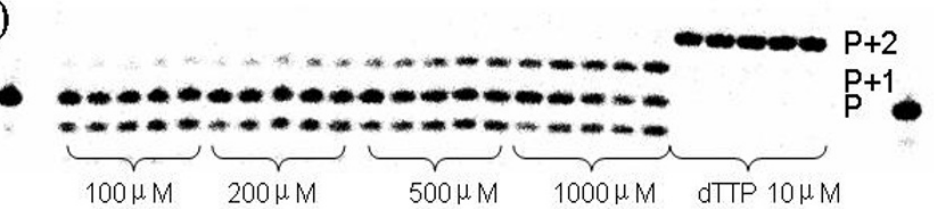

Figure 4 Single incorporation of compound I and II by Taq, Vent (exo') and Therminator DNA polymerase. Time points: 10, 20, 30, 60, and 120 min. a) Incorporation of compound I by Taq DNA polymerase, $\left[P_{1} T_{1}\right]=125 \mathrm{nM} ;$ b) Incorporation of compound I by $V_{\text {ent }}(\text { exo })^{\circ},\left[P_{1} T_{1}\right]=$ $125 \mathrm{nM} ; \mathrm{c}$ ) Incorporation of compound I by Therminator, $\left[\mathrm{P}_{1} \mathrm{~T}_{1}\right]=125 \mathrm{nM}$; d) Incorporation of compound II by Therminator, $\left[\mathrm{P}_{1} \mathrm{~T}_{2}\right]=125 \mathrm{nM}$.

concentration of $500 \mu \mathrm{M}$, with primer $\mathrm{P}_{1}$ and template $\mathrm{T}_{3}$ complex and appropriate concentration of enzyme, samples were taken after $15,30,60,90$, and $120 \mathrm{~min}$, and analyzed by polyacrylamide gel electrophoresis.

The chain elongation results of compound I with Vent $\left(\mathrm{exo}^{-}\right)$polymerase is shown in Figure 5. The primer extension by HIV-1 RT is not very efficient, only three building blocks were extended (data not shown). In contrast, Taq and Vent (exo-) DNA polymerase are able to achieve a full-length elongation, with over $95 \%$ yield of $(\mathrm{P}+7)$ product. Therminator polymerase can also reach the full-length elongation, however, not so sufficient as when using the two other thermostable polymerases (data not shown).
Furthermore, we investigated the chain elongation property of the compound containing two different residues. As the deoxycytidylate residue was not a substrate for all the four tested enzymes, compound III was explored as substrate in this experiment and $\mathrm{P}_{1} \mathrm{~T}_{6}$ was used as primer-template duplex (with a mixed AT sequence in the overhanging part of template) and HIV1 RT as enzyme. Compound III was able to be polymerised by HIV-1 RT, however, only (primer +3 ) product can be obtained (Figure 6). When the kinetics for incorporation of dTMP and dAMP is different, it is difficult to select appropriate reaction conditions for the chain elongation reaction using $\mathrm{dAppdT}$ as reagent and poly $(\mathrm{AT})_{\mathrm{n}}$ as template, avoiding misincorporation.

Table 3 Single incorporation results of compound III-VII by Taq, Vent (exo-) and Therminator DNA polymerase

\begin{tabular}{|c|c|c|c|c|c|}
\hline \multirow[t]{2}{*}{ Compound No. } & \multirow[t]{2}{*}{ Structure } & \multirow[t]{2}{*}{ Primer/Template duplex } & \multicolumn{3}{|c|}{ Single incorporation result, \% } \\
\hline & & & Taq & Vent (exo') & Therminator \\
\hline III & dAppdT & $\mathrm{P}_{1} / \mathrm{T}_{1}$ & $0 \%$ & $0 \%$ & $59 \%$ \\
\hline III & dAppdT & $\mathrm{P}_{1} / \mathrm{T}_{2}$ & $0 \%$ & $0 \%$ & $55 \%$ \\
\hline IV & dGppdG & $\mathrm{P}_{1} / \mathrm{T}_{4}$ & $0 \%$ & $0 \%$ & $74 \%$ \\
\hline V & dGppdC & $\mathrm{P}_{1} / \mathrm{T}_{4}$ & $0 \%$ & $0 \%$ & $48 \%$ \\
\hline v & dGppdC & $\mathrm{P}_{2} / \mathrm{T}_{5}$ & $0 \%$ & $0 \%$ & $0 \%$ \\
\hline VI & dAppdC & $\mathrm{P}_{1} / \mathrm{T}_{1}$ & $0 \%$ & $0 \%$ & $81 \%$ \\
\hline VI & dAppdC & $\mathrm{P}_{2} / \mathrm{T}_{5}$ & $0 \%$ & $0 \%$ & $0 \%$ \\
\hline VII & dCppdC & $\mathrm{P}_{2} / \mathrm{T}_{5}$ & $0 \%$ & $0 \%$ & $0 \%$ \\
\hline
\end{tabular}




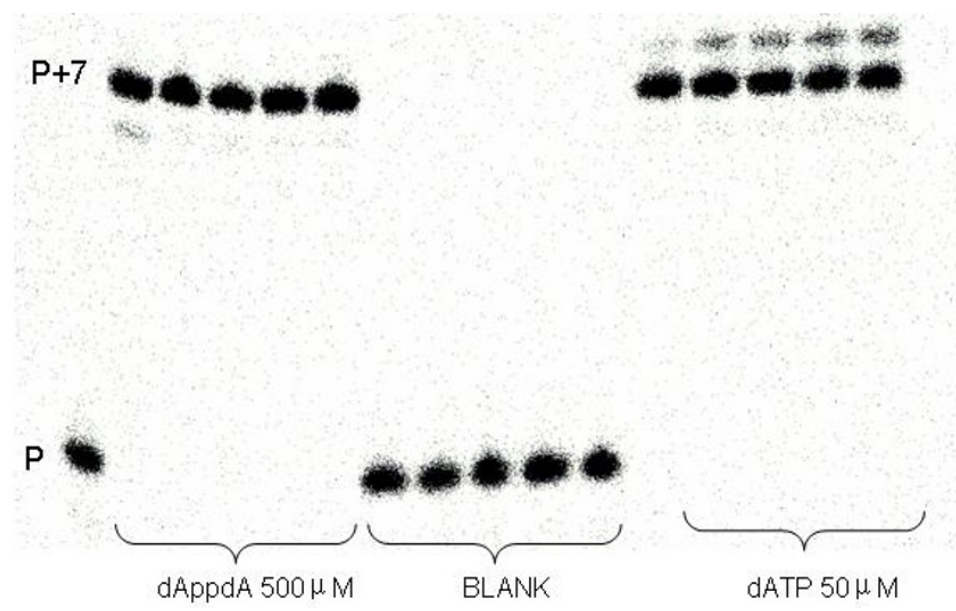

Figure 5 Elongation of $\mathbf{P}_{1} \mathbf{T}_{\mathbf{3}}(\mathbf{1 2 5} \mathrm{nM})$ by Vent $\left(\mathrm{exo}^{-}\right)$polymerase $(\mathbf{0 . 1 0} \mathbf{U} / \boldsymbol{\mu l})$ and compound $\mathrm{I}$. [dAppdA] $=500 \mu \mathrm{M}$, time points: 15, 30, 60, 90 , and $120 \mathrm{~min}$.

\section{Incorporation kinetics}

The kinetic parameters for the incorporation of both compound I and the natural substrate dATP were determined on the basis of the single completed hit model $[21,22] . \mathrm{P}_{1}$ and $\mathrm{T}_{1}$ were used as the primer and template duplex, respectively, HIV-1 RT was used as enzyme. The kinetic parameters $K_{M}$ and $V_{\max }$ and the derived value $V_{\max } / K_{M}$ are given in Table 4 .

As seen in Table 4, compound $\mathbf{I}$ has the similar $\mathrm{V}_{\max }$ value as the natural substrate dATP. However, a large increase in the $\mathrm{K}_{\mathrm{M}}$ value for the incorporation of compound I was observed, this implies a decrease in the enzymatic affinity for dinucleoside pyrophosphate compared to dATP. Thus, the measured ratio $\left(\mathrm{V}_{\max } / \mathrm{K}_{\mathrm{M}}\right)$ toward HIV-1 $\mathrm{RT}$ is 1400 -fold decreased compared to that of dATP. It can be assumed that although compound I was rather efficient as a substrate into a growing DNA strand, the enzyme still prefer the natural dATP as substrate when giving a choice.

\section{Stability studies}

In an earlier enzymatic incorporation study when thermostable DNA polymerases were used, it was observed that the chemical stability of dNTP analogues at elevated temperature $\left(70^{\circ} \mathrm{C}\right)$ influenced the efficiency of incorporation [9]. In this study we have determined the chemical stability of dAppdA, dGppdG, dCppdC, dTppdT and $\mathrm{dGppdC}$ analogues in the $\mathrm{pH}$ range $2-13$ at room temperature $\left(25^{\circ} \mathrm{C}\right)$ and $70^{\circ} \mathrm{C}$ using NMR spectroscopy. All the analogues are found to be stable (no degradation product identified after 3 days) in $\mathrm{pH}$ range $7-12$ at $25^{\circ} \mathrm{C}$ and $70^{\circ} \mathrm{C}$. Generally dNppdN analogues are very stable, and they degrade to nucleotides and nucleosides slowly above $\mathrm{pH} 12$ at $70^{\circ} \mathrm{C}$ and degrade rapidly at less than $\mathrm{pH} 3$, $70^{\circ} \mathrm{C}$. In comparison the $\mathrm{N}$-glycosidic bond of dAppdA, dGppdG, dCppdC analogues is weaker than the P-O-P linkage in acidic medium, since degradation of glycosidic bond was observed in $\mathrm{pH}$ range $4-6.5$ at $70^{\circ} \mathrm{C}$.

\section{Relevance to prebiotic chemistry}

For protein synthesis, Nature uses the principle of putting information (nucleotide triplets) in the leaving group (tRNA). This is necessary because during protein synthesis, information needs to be translated from one biopolymer (RNA) to another (proteins). Putting information in the leaving group may be a general approach to copy

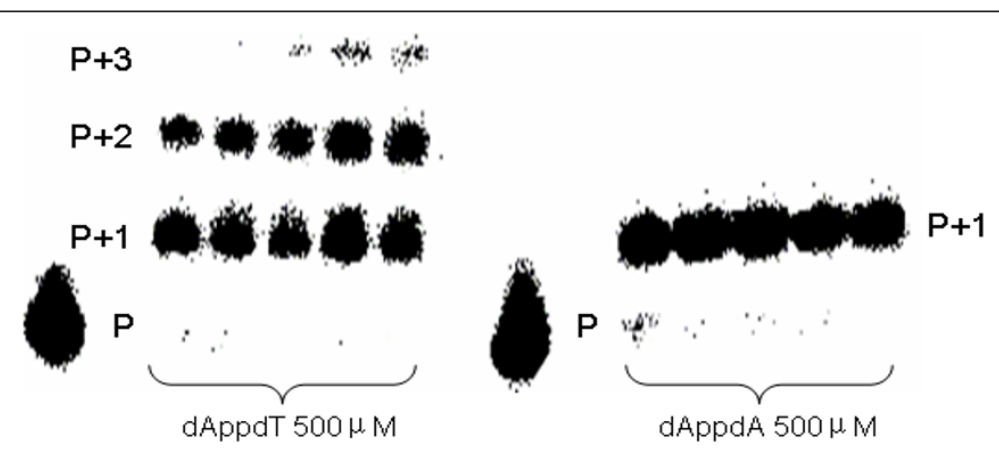

Figure 6 Elongation into $\mathbf{P}_{\mathbf{1}} \mathbf{T}_{\mathbf{6}}(\mathbf{1 2 5} \mathbf{n M})$ by compound III. Time points: 15, 30, 60, 90, and $120 \mathrm{~min}$; [HIV-1 RT] = $0.025 \mathrm{U} / \mu \mathrm{L}$. 
Table 4 The kinetic parameters for incorporation of the natural nucleotide (dAMP) and compound $I$ into $P_{1} T_{1}$ by HIV-1 RT

\begin{tabular}{cccc}
\hline & $\begin{array}{c}\mathbf{V}_{\max } \\
{\left[\mathrm{nM} \cdot \mathbf{m i n}^{-1}\right]}\end{array}$ & $\begin{array}{c}\mathrm{K}_{\mathrm{M}} \\
{[\mu \mathrm{M}]}\end{array}$ & $\begin{array}{c}\mathbf{V}_{\text {max }} / \mathrm{K}_{\mathbf{M}} \\
{\left[\mathrm{min}^{-1}\right]}\end{array}$ \\
\hline dATP & $35 \pm 2$ & $0.3 \pm 0.1$ & $116 \times 10^{-3}$ \\
Compound I & $37 \pm 5$ & $447 \pm 117$ & $0.08 \times 10^{-3}$ \\
\hline [HIV-1 RT] $=0.025 \mathrm{U} / \mathrm{\mu L},\left[\mathrm{P}_{1} \mathrm{~T}_{1}\right]=125 \mathrm{nM}$. & &
\end{tabular}

information and to diversify information in case the polymer that is synthesized (oligonucleotide) is the same as the polymer that is used as information system (oligonucleotide): e.g. a tRNA that is loaded with a nucleotide triplet instead of amino acids, could have been purposely designed by Nature for this goal. Such a system may represent an example of autocatalytic self-replication avoiding product inhibition [23] (when the dinucleotide is built from complementary bases, Scheme 2a, Figure 7) and of the generation of new information (when the dinucleotide is built from non-complementary bases, Scheme 3, Figure 8 ) and would generate molecular networks (Figures 7 and 8). Larger polymers may be formed from shorter oligomers by a ligase reaction (Scheme 4).

The process may be run without waste of material as the nucleotide leaving group is reusable (condensation of $\mathrm{pX}$ and $\mathrm{pY}$ to the $\mathrm{XppY}$ reagent in the presence of an activating agent).

It is obvious that for every reaction there will be a competition between phosphodiester formation between the nucleotides away from the template (Scheme 2a) and between the nucleotides recognized by the template (Scheme 2b).

In the latter case (Scheme 2b, Scheme 3b), we end up in the classical trap of product inhibition. In the first case (Scheme 2a), exponential growth of information without product inhibition may become possible.

Using 4 nucleotides, however, in total 10 possible pyrophosphate linked dinucleotides can be formed from which 4 can be recognized by a homodimer, which makes it unlikely that a process including all 4 nucleotides would have an advantage for prebiotic synthesis of nucleic acids (when compared with 4 nucleoside triphosphates).

Once a diverse set of short oligomers is formed in this way, they can be assembled via Watson-Crick base

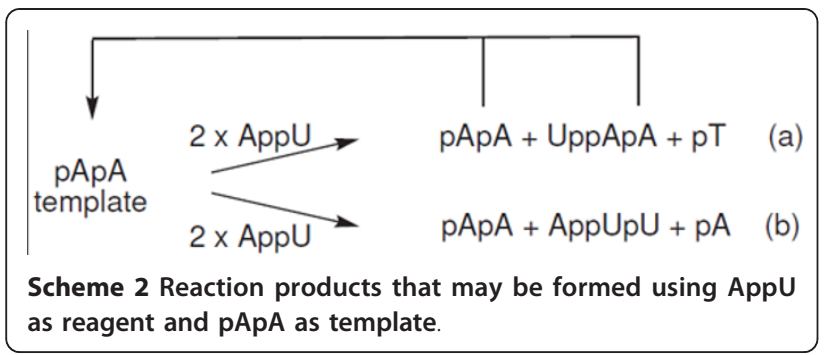

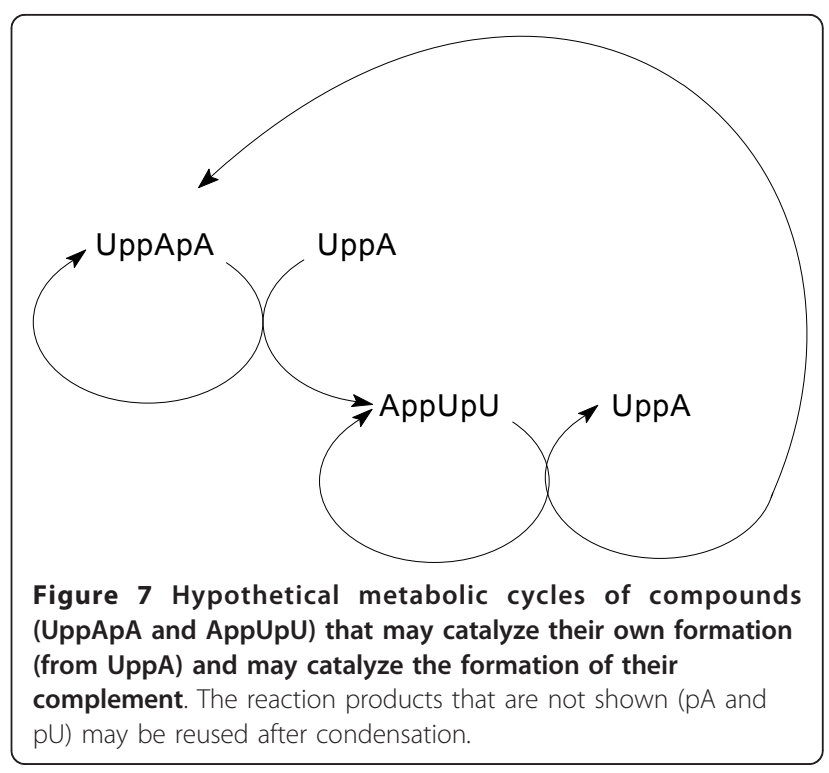

pairing and grow to a larger self-complementary information system (Scheme 4).

However, given the high stability of the pyrophosphate linker, it will not be easy to find an appropriate catalyst for these reactions.

For an experimental set-up, the selection of the interphosphate linking atom $\mathrm{X}$ (Figure 9, $\mathrm{X}$ which could be $\mathrm{O}$, $\mathrm{NH}, \mathrm{S}$ or even imidazole or a larger molecule) and the selection of the reaction circumstances $(\mathrm{pH}$, salt, temperature) to perform dimerization is not easy to make. The properties of $\mathrm{X}$ are important. When both nucleotides are bound to $\mathrm{X}$ in a different way (for example, via an ester and amide linkage), the direction of the dimerization process can be controlled.

\section{Conclusions}

The experimental set-up in this monograph has demonstrated that initial DNA dependent DNA polymerase activity can be ascribed to HIV-RT and several thermostable DNA polymerases using dinucleoside pyrophosphates as substrates. This means that, when using such heterodimers for DNA synthesis (for example dAppdT and $\mathrm{dGppdC}$ ), theoretically, it is possible to synthesize DNA enzymatically using two building blocks instead of four. These initial experiments have been carried out in

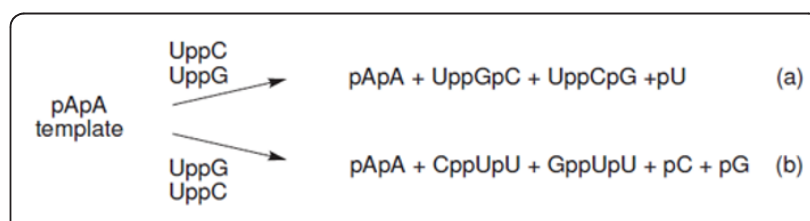

Scheme 3 Reaction products that may be formed using UppC and UppG as reagent and $\mathrm{pApA}$ as template. 


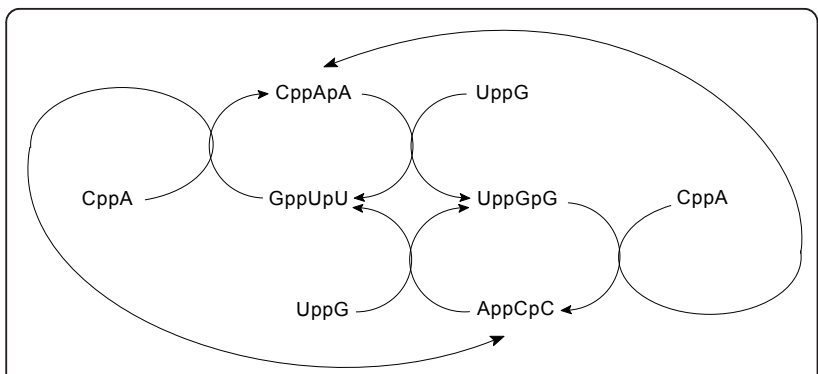

Figure 8 Hypothetical metabolic cycles of four dimers (ZppXpY) as generated from two non-selfcomplementary building blocks (CppA and UppG). The reaction products that are not shown ( $\mathrm{pU}, \mathrm{pG}, \mathrm{pA}, \mathrm{pC})$ may be reused after condensation.

the light of trying to find model compounds that could have been used in a primitive life form to build up an information system while still having the capacity for exponential growth of this information.

The general principle that has been used by Nature for protein synthesis, i.e., to incorporate information in leaving groups, may as well have been used by Nature to select its most abundant information system itself. Future experiments are aimed to find the appropriate X (Figure 9) together with the optimal reaction circumstances to realize metabolic cycles as depicted in Figures 7 and 8.

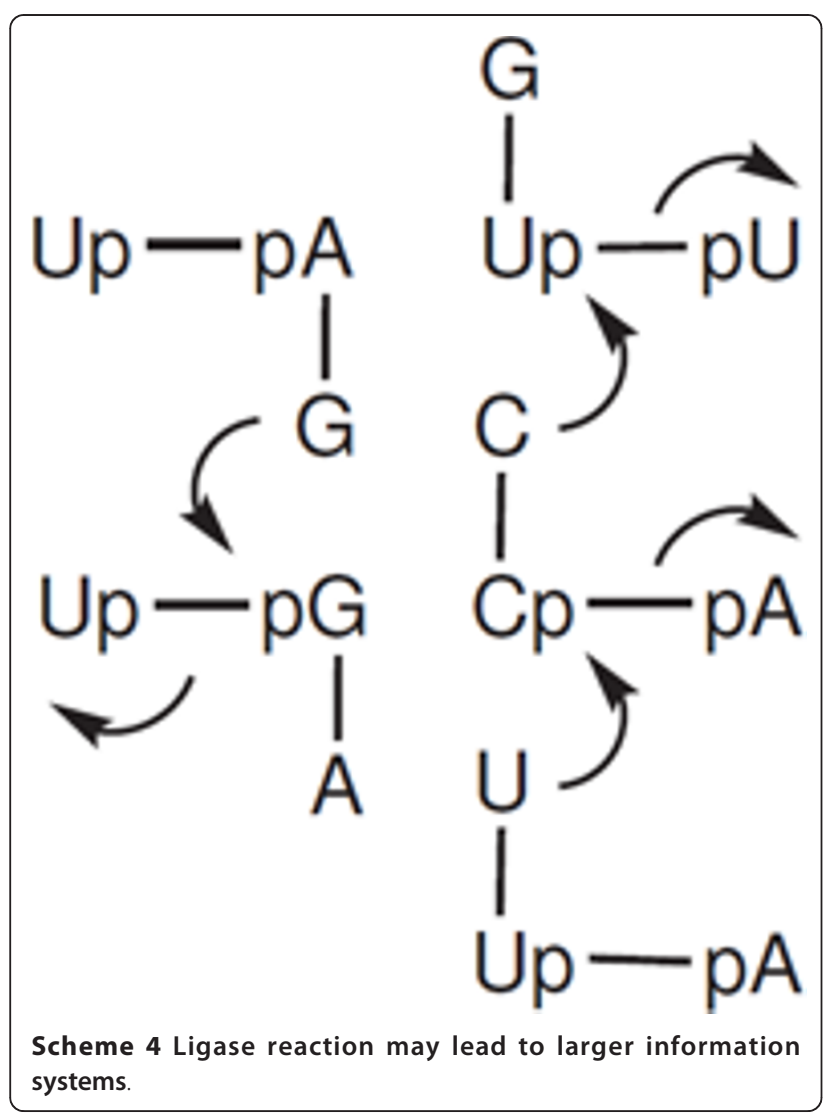

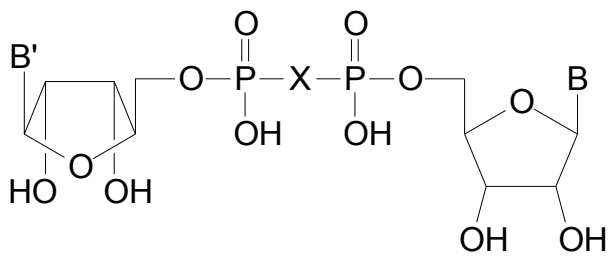

Figure 9 Structure of a pyrophosphate linked nucleotide dimer.

\section{Experimental Section \\ General}

For all reactions, chemicals of analytical or synthetic grade were obtained from commercial sources and were used without purification. Technical solvents were obtained from Brenntag (Deerlijk, Belgium). Analytical thin Layer Chromatography was performed on Alugram ${ }^{(B)}$ silica gel UV254 mesh 60, $0.20 \mathrm{~mm}$ (Macherey-Nagel). NMR Spectra were recorded on a Brucker Avance ${ }^{\mathrm{TM}}$ II $300 \mathrm{MHz}$ or $500 \mathrm{MHz}$ NMR spectrometer. Chemical shifts are expressed as $\delta$ units (part per million) down field from TMS (tetramethyl silane) for ${ }^{1} \mathrm{H}$ and ${ }^{13} \mathrm{C} .{ }^{31} \mathrm{P}$ NMR chemical shifts are referenced to an external $85 \%$ $\mathrm{H}_{3} \mathrm{PO}_{4}$ standard $(\delta=0.00 \mathrm{ppm})$. Exact mass spectra were obtained with a quadrupol/orthogonal-acceleration timeof-flight tandem mass spectrometer (Q-Tof 2, Micromass) equipped with a standard electrospray ionization (ESI) source. HPLC was performed on Waters 1525-2487 system using C18 column by a gradient elution of acetonitrile and $50 \mathrm{mM}$ triethylammonium bicarbonate (TEAB) buffer.

\section{Synthesis of deoxyadenosine-5'-phosphoroimidazole}

General Procedure (I): Deoxyadeosine-5'-monophosphate (100 mg, 0.30 mmoles) was dissolved in dry DMSO $(2 \mathrm{~mL})$, pulverized triphenylphosphine $(327 \mathrm{mg}$, $0.96 \mathrm{mmoles}$ ), 2,2-dipyridyl disulfide (211 mg, 0.96 mmoles) and imidazole (327 mg, 4.8 mmoles) were added to the solution, the resulting yellow solution was stirred at room temperature for $50 \mathrm{~min}$, after completion the mixture was poured into $0.1 \mathrm{M}$ sodium iodide solution in cold acetone $(30 \mathrm{~mL})$. The white precipitate was collected by centrifugation and washed several times with cold fresh acetone. The product was dried in desicator for $1 \mathrm{~h}$.; the white solid was stored at $-20^{\circ} \mathrm{C}$ (99 mg, yield 87\%). ${ }^{1} \mathrm{H}$ NMR (500 $\mathrm{MHz}, \mathrm{D}_{2} \mathrm{O}$ ): $\delta=8.07$ $\left(\mathrm{s}, 1 \mathrm{H}, \mathrm{H}_{8}\right), 7.92\left(\mathrm{~s}, 1 \mathrm{H}, \mathrm{H}_{2}\right), 6.20(\mathrm{t}, 1 \mathrm{H}, J=6.2 \mathrm{~Hz}$, $\left.\mathrm{H}_{1^{\prime}}\right), 4.55\left(\mathrm{~m}, 1 \mathrm{H}, \mathrm{H}_{3^{\prime}}\right), 4.13\left(\mathrm{~m}, 3 \mathrm{H}, \mathrm{H}_{4^{\prime}}+\mathrm{H}_{5^{\prime}}\right), 2.50(\mathrm{~m}$, $1 \mathrm{H}, \mathrm{H}_{2}$ 'a $), 2.43\left(\mathrm{~m}, 1 \mathrm{H}, \mathrm{H}_{2} \mathrm{~b}\right) ;{ }^{13} \mathrm{C}$ NMR $(125 \mathrm{MHz}$, $\left.\mathrm{D}_{2} \mathrm{O}\right): \delta=155.1,152.6,148.4,140.1,118.4,86.5,84.4$, 71.2, 66.0, 40.0; ${ }^{31} \mathrm{P}$ NMR (121 MHz, $\left.\mathrm{D}_{2} \mathrm{O}\right): \delta=-11.23$; HRMS: $[\mathrm{M}-\mathrm{H}]^{-}$calculated for $\mathrm{C}_{20} \mathrm{H}_{25} \mathrm{~N}_{10} \mathrm{O}_{11} \mathrm{P}_{2} 643.1185$, found: 643.1183 . 


\section{Synthesis of $\mathrm{P}^{1}, \mathrm{P}^{2}$-bis(2'-deoxyadenosin-5'-yl) Pyrophosphate (dAppdA)}

General Procedure (II): A solution of 2'-deoxyadeonosine5'-monophosphate (100 mg, 0.30 mmoles), 2'-deoxyadeonosine-5'-phosphorimidazolide (114 mg, 0.30 mmoles), zinc chloride (35 mg, 0.30 mmoles) in $0.2 \mathrm{M}$ N-ethylmorpholine buffer ( $3 \mathrm{~mL}, \mathrm{pH} 7.5$ ) was stirred at room temperature under argon for 2 days. The reaction was monitored by TLC (i-PrOH/ $\left.\mathrm{NH}_{3} / \mathrm{H}_{2} \mathrm{O} 7: 1: 2\right)$ and ${ }^{31} \mathrm{P} \mathrm{NMR}$, quenched the reaction with $0.25 \mathrm{M}$ ethylenediaminetetraacetic acid (EDTA) in order to breakdown the nucleotide-metal complex, then the mixture was lyophilized affording a white solid. The product was isolated by HPLC purification on a C18 column, running with a gradient of $\mathrm{CH}_{3} \mathrm{CN}$ in $50 \mathrm{mM}$ triethylammonium (TEAB) buffer. Yield 28\% (from HPLC purification profile). ${ }^{1} \mathrm{H}$ NMR $\left(500 \mathrm{MHz}, \mathrm{D}_{2} \mathrm{O}\right): \delta=8.02$ (s, $\left.2 \mathrm{H}, \mathrm{H}_{8}\right), 7.90\left(\mathrm{~s}, 2 \mathrm{H}, \mathrm{H}_{2}\right), 6.16\left(\mathrm{t}, 2 \mathrm{H}, J=5.7 \mathrm{~Hz}, \mathrm{H}_{1}\right), 4.49$ (m, 2H, $\mathrm{H}_{3}$ ), $4.07\left(\mathrm{~m}, 4 \mathrm{H}, \mathrm{H}_{5^{\prime}}\right), 4.02\left(\mathrm{~m}, 2 \mathrm{H}, \mathrm{H}_{4^{\prime}}\right), 2.46(\mathrm{~m}$, $2 \mathrm{H}, \mathrm{H}_{2}$ 'a), 2.40 (m, 2H, $\left.\mathrm{H}_{2}{ }^{\prime} \mathrm{b}\right) ;{ }^{13} \mathrm{C}$ NMR (125 MHz, $\left.\mathrm{D}_{2} \mathrm{O}\right)$ : $\delta=155.1,152.3,148.4,140.1,118.4,86.1,84.1,71.2,66.0$, 40.0; ${ }^{31} \mathrm{P}$ NMR (121 MHz, $\left.\mathrm{D}_{2} \mathrm{O}\right): \delta=-11.27$; HRMS: [M$\mathrm{H}]^{-}$calculated for $\mathrm{C}_{20} \mathrm{H}_{25} \mathrm{~N}_{10} \mathrm{O}_{11} \mathrm{P}_{2}$ 643.1185, found: 643.1183.

\section{Synthesis of $\mathrm{P}^{1}, \mathrm{P}^{2}$-bis(2'-deoxythymidin-5'-yl) Pyrophosphate (dTppdT)}

The general procedure (I) was applied using thymidine-5'monophosphate (300 mg, 0.93 mmoles), triphenylphosphine (1.01 g, 2.98 mmoles), 2,2-dipyridyl disulfide (655 mg, 2,98 mmoles) and imidazole (1.02 g, 14.9 mmoles). After reaction the obtained product was applied to general procedure (II) using thymidine-5'-monophosphate (100 mg, 0.31 mmoles), thymidine-5'-phosphorimidazolide (115 mg, $0.31 \mathrm{mmoles}$ ) and zinc chloride (36 mg, 0.31 mmoles). After purification obtained white solid product (yield 35\% (from HPLC purification profile)). ${ }^{1} \mathrm{H}$ NMR $\left(500 \mathrm{MHz}, \mathrm{D}_{2} \mathrm{O}\right): \delta=7.71\left(\mathrm{~s}, 2 \mathrm{H}, \mathrm{H}_{6}\right), 6.29(\mathrm{t}, 2 \mathrm{H}, J=7.0$ $\mathrm{Hz}, \mathrm{H}_{1}$ ) , 4.56-4.61 (m, 2H, $\mathrm{H}_{3}$ ), 4.16-4.17 (m, $2 \mathrm{H}, \mathrm{H}_{4^{\prime}}$ ), 4.12-4.13 (m, 4H, $\mathrm{H}_{5}$ ), 2.32-2.36 (m, 4H, $\mathrm{H}_{2}$ ), $1.91(\mathrm{~s}, 6 \mathrm{H}$, $\left.\mathrm{CH}_{3}\right) ;{ }^{13} \mathrm{C}$ NMR $\left(125 \mathrm{MHz}, \mathrm{D}_{2} \mathrm{O}\right): \delta=166.1,151.3,137.1$, $111.4,85.0,84.9,70.5,65.0,38.3,11.4 ;{ }^{31} \mathrm{P}$ NMR (121 $\left.\mathrm{MHz}, \mathrm{D}_{2} \mathrm{O}\right): \delta=-11.62$; HRMS: [M-H] ${ }^{-}$calculated for $\mathrm{C}_{20} \mathrm{H}_{28} \mathrm{~N}_{4} \mathrm{O}_{15} \mathrm{P}_{2}$ 625.0953, found: 625.0962

\section{Synthesis of $\mathrm{P}^{1}-\left(2^{\prime}\right.$-deoxyadenosin-5'-yl) $\mathrm{P}^{2}-\left(2^{\prime}-\right.$ deoxythymidin-5'-yl) Pyrophosphate (dAppdT)}

The general procedure (II) was applied using 2'-deoxyadeonosine- 5'-phosphorimidazolide (100 mg, $0.26 \mathrm{mmoles}$ ) and thymidine-5'-monophosphate ( $85 \mathrm{mg}, 0.26$ mmoles) and zinc chloride (30 mg, 0.26 mmoles). After purification obtained white solid product (yield 18\% (from HPLC purification profile)) ${ }^{1} \mathrm{H}$ NMR $\left(500 \mathrm{MHz}, \mathrm{D}_{2} \mathrm{O}\right): \delta=8.36$ (s, $1 \mathrm{H}, \mathrm{H}_{8}-\mathrm{A}$ ), 8.10 (s, 1H, $\left.\mathrm{H}_{2}-\mathrm{A}\right), 7.31$ (s, $\left.1 \mathrm{H}, \mathrm{H}_{6}-\mathrm{T}\right), 6.39$ $\left(\mathrm{t}, 1 \mathrm{H}, J=6.0 \mathrm{~Hz}, \mathrm{H}_{1},-\mathrm{A}\right), 6.15\left(\mathrm{t}, 1 \mathrm{H}, J=6.0 \mathrm{~Hz}, \mathrm{H}_{1},-\mathrm{T}\right)$, 4.63-4.65 (m, $\left.1 \mathrm{H}, \mathrm{H}_{3},-\mathrm{A}\right), 4.40-4.42\left(\mathrm{~m}, 1 \mathrm{H}, \mathrm{H}_{3},-\mathrm{T}\right)$, 4.164.18 (m, 1H, $\left.\mathrm{H}_{4}, \mathrm{~A}\right)$, 4.07-4.00 (m, 5H, $\mathrm{H}_{4},-\mathrm{T}, \mathrm{H}_{5},-\mathrm{A}, \mathrm{H}_{5}$,$\mathrm{T})$, 2.71-2.75 (m, $\left.1 \mathrm{H}, \mathrm{H}_{2}{ }^{\prime} \mathrm{a}-\mathrm{A}\right), 2.46-2.50\left(\mathrm{~m}, 1 \mathrm{H}, \mathrm{H}_{2}{ }^{\prime} \mathrm{a}-\mathrm{T}\right)$, 2.11-2.15 (m, 2H, $\left.\mathrm{H}_{2} \mathrm{~b}-\mathrm{T}\right), 2.04-2.08$ (m, 2H, $\left.\mathrm{H}_{2} \mathrm{~b}^{\mathrm{b}}-\mathrm{A}\right), 1.67$ $\left(\mathrm{s}, 3 \mathrm{H}, \mathrm{T}-\mathrm{CH}_{3}\right) ;{ }^{13} \mathrm{C}$ NMR $\left(125 \mathrm{MHz}, \mathrm{D}_{2} \mathrm{O}\right): \delta=181.4$, 172.3, 155.3, 152.4, 148.5, 139.7, 136.1, 118.4, 111.4, 85.6, 84.8, 84.6, 83.3, 71.0, 71.1, 65.4, 65.3, 38.9, 38.6, $12.3 ;{ }^{31} \mathrm{P}$ NMR (121 MHz, $\left.\mathrm{D}_{2} \mathrm{O}\right): \delta=-11.41$; HRMS: [M-H] ${ }^{-}$calculated for $\mathrm{C}_{20} \mathrm{H}_{26} \mathrm{~N}_{7} \mathrm{O}_{13} \mathrm{P}_{2}$ 634.1069, found: 634.1063.

\section{Synthesis of $\mathrm{P}^{1}, \mathrm{P}^{2}$-bis(2'-deoxyguanosin-5'-yl) Pyrophosphate (dGppdG)}

The general procedure (I) was applied using using 2'-deoxyguanosine-5'-monophosphate (300 mg, $0.78 \mathrm{mmoles})$, triphenylphosphine ( $850 \mathrm{mg}, 2.50 \mathrm{mmoles}$ ), 2,2-dipyridyl disulfide (549 mg, 2,50 mmoles) and imidazole (850 mg, 12.9 mmoles). After reaction the obtained product was applied to general procedure (II) using 2'-deoxyguanosine5'-monophosphate (100 mg, 0.26 mmoles), 2'-deoxyguanosine-5'-phosphorimidazolide (102 $\mathrm{mg}, 0.26 \mathrm{mmoles}$ ) and $\mathrm{Pd}\left(\mathrm{NO}_{3}\right)_{2}$ (60 mg, 0.36 mmoles). After purification obtained white solid product (yield 33\% (from HPLC purification profile)). ${ }^{1} \mathrm{H}$ NMR (500 MHz, $\left.\mathrm{D}_{2} \mathrm{O}\right): \delta=7.86(\mathrm{~s}$, $\left.2 \mathrm{H}, \mathrm{H}_{6}\right), 6.11\left(\mathrm{t}, 2 \mathrm{H}, J=6.5 \mathrm{~Hz}, \mathrm{H}_{1}\right), 4.54-4.56(\mathrm{~m}, 2 \mathrm{H}$, $\mathrm{H}_{3}$ ), 4.05-4.07 (m, $2 \mathrm{H}, \mathrm{H}_{4}$ ), 4.03-4.05 (m, 4H, $\mathrm{H}_{5}$ ), 2.54$2.63\left(\mathrm{~m}, 2 \mathrm{H}, \mathrm{H}_{2}\right.$ 'a $), 2.33-2.36\left(\mathrm{~m}, 2 \mathrm{H}, \mathrm{H}_{2}{ }^{\prime} \mathrm{b}\right) ;{ }^{13} \mathrm{C}$ NMR $(125$ $\left.\mathrm{MHz}, \mathrm{D}_{2} \mathrm{O}\right): \delta=162.1,156.3,150.8,136.3,116.3,85.1$, 83.0, 70.8, 65.2, 38.4; ${ }^{31} \mathrm{P}$ NMR (121 MHz, $\left.\mathrm{D}_{2} \mathrm{O}\right): \delta=$ -11.40; HRMS: [M-H] ${ }^{-}$calculated for $\mathrm{C}_{20} \mathrm{H}_{25} \mathrm{~N}_{10} \mathrm{O}_{13} \mathrm{P}_{2}$ 675.1083, found: 675.1092 .

\section{Synthesis of $\mathrm{P}^{1}-\left(2^{\prime}\right.$-deoxyguanosin-5'-yl) $\mathrm{P}^{2}-\left(2^{\prime}-\right.$ deoxycytidin-5'-yl) Pyrophosphate (dGppdC)}

The general procedure (I) was applied using using 2'-deoxyguanosine-5'-monophosphate (300 mg, $0.78 \mathrm{mmoles})$, triphenylphosphine (850 mg, 2.50 mmoles), 2,2-dipyridyl disulfide (549 mg, 2,50 mmoles) and imidazole (850 mg, 12.9 mmoles). After reaction the obtained product was applied to general procedure (II) using 2'-deoxyguanosine5'-phosphorimidazolide (100 mg, $0.25 \mathrm{mmoles}), 2$ '-deoxycytidine-5'-monophosphate (82 mg, 0.25 mmoles) and Pd $\left(\mathrm{NO}_{3}\right)_{2}$ (58 mg, 0.25 mmoles). After purification obtained white solid product (yield 15\% (from HPLC purification profile)). ${ }^{1} \mathrm{H}$ NMR $\left(500 \mathrm{MHz}, \mathrm{D}_{2} \mathrm{O}\right): \delta=8.04\left(\mathrm{~s}, 1 \mathrm{H}, \mathrm{H}_{8^{-}}\right.$ G), $7.82\left(\mathrm{~d}, 1 \mathrm{H}, J=7.5 \mathrm{~Hz}, \mathrm{H}_{6}-\mathrm{C}\right), 6.30(\mathrm{t}, 1 \mathrm{H}, J=7.0 \mathrm{~Hz}$, $\mathrm{H}_{1}$ - $\mathrm{G}$ ), 6.25 (t, $\left.1 \mathrm{H}, J=6.5 \mathrm{~Hz}, \mathrm{H}_{1},-\mathrm{C}\right), 5.97$ (d, $1 \mathrm{H}, J=7.0$ $\mathrm{Hz}, \mathrm{H}_{5}-\mathrm{C}$ ), 4.63-4.67 (m, $\left.1 \mathrm{H}, \mathrm{H}_{3}, \mathrm{G}\right), 4.52-4.54$ (m, $1 \mathrm{H}$, $\mathrm{H}_{3}, \mathrm{C}$ ), 4.23-4.25 (m, 1H, $\left.\mathrm{H}_{4},-\mathrm{G}\right), 4.15-4.17$ (m, $1 \mathrm{H}, \mathrm{H}_{4}, \mathrm{C}$ ), 4.12-4.15 (m, 4H, $\left.\mathrm{H}_{5},-\mathrm{G}, \mathrm{H}_{5}, \mathrm{C}\right)$, 2.77-2.82 (m, $1 \mathrm{H}, \mathrm{H}_{2} \mathrm{a}^{-} \mathrm{G}$ ), 2.48-2.50 (m, $\left.1 \mathrm{H}, \mathrm{H}_{2}{ }^{\prime} \mathrm{a}-\mathrm{C}\right), 2.36-2.41$ (m, $\left.1 \mathrm{H}, \mathrm{H}_{2}{ }^{\prime} \mathrm{b}-\mathrm{C}\right), 2.18-$ 2.24 (m, $\left.1 \mathrm{H}, \mathrm{H}_{2}{ }^{\prime} \mathrm{b}-\mathrm{G}\right) ;{ }^{13} \mathrm{C}$ NMR $\left(125 \mathrm{MHz}, \mathrm{D}_{2} \mathrm{O}\right): \delta=$ $165.6,161.5,156.9,150.9,140.9,136.5,116.3$, 95.9, 85.5, 
85.2, 85.0, 83.0, 70.9, 70.2, 65.3, 64.8, 39.2, 38.1; ${ }^{31} \mathrm{P}$ NMR $\left(121 \mathrm{MHz}, \mathrm{D}_{2} \mathrm{O}\right): \delta=-11.40$; HRMS: [M-H] ${ }^{-}$calculated for $\mathrm{C}_{19} \mathrm{H}_{25} \mathrm{~N}_{8} \mathrm{O}_{13} \mathrm{P}_{2}$ 635.1022, found: 635.1099 .

\section{Synthesis of $P^{1}-\left(2^{\prime}\right.$-deoxyadenosin-5'-yl) $P^{2}-\left(2^{\prime}-\right.$} deoxythymidin-5'-yl) Pyrophosphate (dAppdC)

The general procedure (II) was applied using 2'-deoxyadeonosine-5'-phosphorimidazolide (100 $\mathrm{mg}, 0.26 \mathrm{mmoles})$, 2'-deoxycytidine-5'-monophosphate ( $85 \mathrm{mg}, 0.26 \mathrm{mmoles})$ and zinc chloride ( $30 \mathrm{mg}, 0.26 \mathrm{mmoles})$. After purification obtained white solid product (yield 18\% (from HPLC purification profile)). ${ }^{1} \mathrm{H}$ NMR $\left(500 \mathrm{MHz}, \mathrm{D}_{2} \mathrm{O}\right): \delta=8.38(\mathrm{~s}$, $\left.1 \mathrm{H}, \mathrm{H}_{8}-\mathrm{A}\right), 8.10\left(\mathrm{~s}, 1 \mathrm{H}, \mathrm{H}_{2}-\mathrm{A}\right), 7.53\left(\mathrm{~d}, 1 \mathrm{H}, J=6.0 \mathrm{~Hz}, \mathrm{H}_{6^{-}}\right.$ C), $6.40\left(\mathrm{t}, 1 \mathrm{H}, J=5.5 \mathrm{~Hz}, \mathrm{H}_{1^{\prime}}-\mathrm{A}\right), 6.08(\mathrm{t}, 1 \mathrm{H}, J=5.5 \mathrm{~Hz}$, $\left.\mathrm{H}_{1},-\mathrm{C}\right), 5.68\left(\mathrm{~d}, 1 \mathrm{H}, J=6.5 \mathrm{~Hz}, \mathrm{H}_{5}-\mathrm{C}\right), 4.65-4.67(\mathrm{~m}, 1 \mathrm{H}$, $\mathrm{H}_{3}$-A), 4.37-4.39 (m, $\left.1 \mathrm{H}, \mathrm{H}_{3^{\prime}}-\mathrm{C}\right)$, 4.20-4.21 (m, $1 \mathrm{H}, \mathrm{H}_{4}$ - $\mathrm{A}$ ), 4.09-4.05 (m, 5H, $\left.\mathrm{H}_{5},-\mathrm{A}, \mathrm{H}_{5},-\mathrm{C}, \mathrm{H}_{4}, \mathrm{C}\right), 2.73-2.78(\mathrm{~m}, 1 \mathrm{H}$, $\left.\mathrm{H}_{2^{\prime} \mathrm{a}^{-}} \mathrm{A}\right), 2.47-2.51\left(\mathrm{~m}, 1 \mathrm{H}, \mathrm{H}_{2^{\prime} \mathrm{a}^{-}}-\mathrm{C}\right), 2.22-2.26\left(\mathrm{~m}, 1 \mathrm{H}, \mathrm{H}_{2^{\prime} \mathrm{b}^{-}}\right.$ C), $1.99-2.03\left(\mathrm{~m}, 1 \mathrm{H}, \mathrm{H}_{2}{ }^{\prime} \mathrm{b}-\mathrm{A}\right) ;{ }^{13} \mathrm{C}$ NMR $\left(125 \mathrm{MHz}, \mathrm{D}_{2} \mathrm{O}\right)$ : $\delta=165.5,157.0,155.3,152.4,148.5,140.6,139.6,118.3$, 95.8, 85.7, 85.6, 85.2, 83.4, 71.2, 70.4, 65.5, 65.1, 39.5, 38.8; ${ }^{31} \mathrm{P}$ NMR $\left(121 \mathrm{MHz}, \mathrm{D}_{2} \mathrm{O}\right): \delta=-11.34$; HRMS: [M-H] ${ }^{-}$calculated for $\mathrm{C}_{20} \mathrm{H}_{25} \mathrm{~N}_{8} \mathrm{O}_{12} \mathrm{P}_{2}$ 619.1073, found: 619.1089

\section{Synthesis of $\mathrm{P}^{1}, \mathrm{P}^{2}$-bis(2'-deoxycytidin-5'-yl) Pyrophosphate (dCppdC)}

The general procedure (I) was applied using 2'-deoxycytidine-5'-monophosphate (300 mg, $0.93 \mathrm{mmoles}$ ), triphenylphosphine (1.01 g, $2.98 \mathrm{mmoles}), 2$,2-dipyridyl disulfide (655 mg, 2,98 mmoles) and imidazole (1.02 g, 14.9 mmoles). After reaction the obtained product was applied to general procedure (II) using 2'-deoxycytidine-5'-monophosphate (100 mg, $0.31 \mathrm{mmoles}), 2$ '-deoxycytidine-5'phosphorimidazolide $(115 \mathrm{mg}, 0.31 \mathrm{mmoles})$ and zinc chloride (36 mg, 0.31 mmoles). After purification obtained white solid product (yield 26\% (from HPLC purification profile)). ${ }^{1} \mathrm{H}$ NMR $\left(500 \mathrm{MHz}, \mathrm{D}_{2} \mathrm{O}\right): \delta=7.90(\mathrm{~d}, J=7.6$ $\left.\mathrm{Hz}, 2 \mathrm{H}, \mathrm{H}_{6}\right), 6.31\left(\mathrm{t}, 2 \mathrm{H}, J=6.8 \mathrm{~Hz}, \mathrm{H}_{1^{\prime}}\right), 6.05(\mathrm{~d}, 2 \mathrm{H}, J=$ $\left.7.5 \mathrm{~Hz}, \mathrm{H}_{5}\right), 4.52-4.56\left(\mathrm{~m}, 2 \mathrm{H}, \mathrm{H}_{3^{\prime}}\right), 4.14-4.18(\mathrm{~m}, 6 \mathrm{H}$, $\left.\mathrm{H}_{4^{\prime}}+\mathrm{H}_{5^{\prime}}\right), 2.35-2.41\left(\mathrm{~m}, 2 \mathrm{H}, \mathrm{H}_{2^{\prime} \mathrm{a}}\right), 2.19-2.28\left(\mathrm{~m}, 2 \mathrm{H}, \mathrm{H}_{2^{\prime} \mathrm{b}}\right)$; ${ }^{13} \mathrm{C}$ NMR $\left(125 \mathrm{MHz}, \mathrm{D}_{2} \mathrm{O}\right): \delta=165.7,157.2,141.2,96.2$, 85.5, 85.0, 70.4, 64.9, 39.2; ${ }^{31} \mathrm{P}$ NMR $\left(121 \mathrm{MHz}, \mathrm{D}_{2} \mathrm{O}\right): \delta=$ -8.84; HRMS: $[\mathrm{M}-\mathrm{H}]^{-}$calculated for $\mathrm{C}_{18} \mathrm{H}_{25} \mathrm{~N}_{6} \mathrm{O}_{13} \mathrm{P}_{2}$ 595.0960, found: 595.0954 .

\section{Oligodeoxyribonucleotides preparation}

Oligodeoxyribonucleotides $\mathrm{P}_{1}, \mathrm{P}_{2}, \mathrm{~T}_{1}-\mathrm{T}_{6}$ were purchased from Sigma Genosys. The concentrations were measured with a Varian Cary-300-Bio UV spectrophotometer. The lyophilized oligonucleotides were dissolved in diethylpyrocarbonate (DEPC)-treated water and stored at $-20^{\circ} \mathrm{C}$. The primer oligonucleotides were $5{ }^{\prime}{ }^{33} \mathrm{P}$-labeled with 5 $\left[\gamma^{33} \mathrm{P}\right]$-ATP (Perkin Elmer) using $\mathrm{T}_{4}$ polynucleotide kinase (NEB) according to standard procedures. The labelled oligonucleotide was further purified using Illustra TM Microspin TM G-25 columns (GE Healthcare).

\section{DNA polymerase reactions}

End-labelled primer was annealed to its template by combining primer and template in a molar ratio of $1: 2$ and heating the mixture to $70^{\circ} \mathrm{C}$ for $10 \mathrm{~min}$ followed by slow cooling to room temperature over a period of $1.5 \mathrm{~h}$. For the incorporation of compound I-VII, a series of $20 \mu \mathrm{L}$ batch reactions were performed with the enzyme (HIV-1 $\mathrm{RT}$, Taq, Vent (exo-), Therminator DNA polymerase). The final mixture contained $125 \mathrm{nM}$ primer template complex, RT buffer $(250 \mathrm{mM}$ Tris. $\mathrm{HCl}, 250 \mathrm{mM} \mathrm{KCl}, 50 \mathrm{mM}$ $\mathrm{MgCl}_{2}, 2.5 \mathrm{mM}$ spermidine, $50 \mathrm{mM}$ dithiothreitol (DTT); $\mathrm{pH}$ 8.3), appropriate concentration of enzyme, and different concentrations of dinucleoside diphosphates building blocks $(1 \mathrm{mM}, 500 \mu \mathrm{M}, 200 \mu \mathrm{M}$ and $100 \mu \mathrm{M})$. In the control reaction a $10 \mu \mathrm{M}$ dATP was used as reference. The mixture was incubated at $37^{\circ} \mathrm{C}$ or $75^{\circ} \mathrm{C}$ respectively, and aliquots were quenched after 10, 20, 30, 60 and $120 \mathrm{~min}$. For elongation experiments, the same mixture with appropriate primer/template hybrid was incubated at $37^{\circ} \mathrm{C}$ or $75^{\circ} \mathrm{C}$ and aliquots were quenched after $15,30,60,90$, $120 \mathrm{~min}$.

\section{Steady-state kinetics of single nucleotide incorporation}

The steady-state kinetics of single nucleotide incorporation of compound I and the natural nucleoside triphosphate (dATP) was determined by a gel-based polymerase assay. In all the experiments, the template $T_{1}$ and the primer $P_{1}$ were used. The primer and template in a 1:2 molar ratio were hybridised in a buffer containing $20 \mathrm{mM}$ Tris. $\mathrm{HCl}, 10 \mathrm{mM} \mathrm{KCl}, 2 \mathrm{mM} \mathrm{MgSO}_{4}, 0.1 \%$ Triton X-100, pH 8.3 and used in an amount to provide $125 \mathrm{nM}$ concentration of the primer in each $20 \mu \mathrm{L}$ reaction. A range of building block concentrations between $10 \mu \mathrm{M}$ and $1 \mathrm{mM}$ for the phosphoramidate and between $0.1 \mu \mathrm{M}$ and $10 \mu \mathrm{M}$ for the natural building block was used. The final concentrations of primer-template complex and HIV-1 RT were $125 \mathrm{nM}$, and $0.025 \mathrm{U} / \mu \mathrm{L}$, respectively. Reaction mixtures were incubated at $37^{\circ} \mathrm{C}$ and aliquots were drawn at 6 different time intervals. The reactions were quenched by addition of a buffer containing $80 \%$ formamide, $2 \mathrm{mM}$ EDTA and 1X TBE buffer. The analysis of polymerase reaction was performed by polyacrylamide gel electrophoresis (see detailed protocol below). The incorporation rates (V) were calculated based on the percentage of the extended oligonucleotide in the mixture ( $\mathrm{P}+1$ band). The kinetic parameters $\left(\mathrm{V}_{\mathrm{Max}}\right.$ and $\left.\mathrm{K}_{\mathrm{M}}\right)$ were determined by plotting $\mathrm{V}\left(\mathrm{nM} / \mathrm{min}^{-1}\right)$ versus substrate concentration $(\mu \mathrm{M})$ and fitting the data to a non-linear Michaelis-Menten regression using GraphPad Prism Software version 5.0. 


\section{Electrophoresis}

All polymerase reaction aliquots $(2.5 \mu \mathrm{L})$ were quenched by the addition of $10 \mu \mathrm{L}$ of loading buffer ( $90 \%$ formamide, $0.05 \%$ bromophenol blue, $0.05 \%$ xylene cyanol and $50 \mathrm{mM}$ ethylenediaminetetraacetic acid). Samples were heated at $85^{\circ} \mathrm{C}$ for 3 minutes prior to analysis by electrophoresis for $2.5 \mathrm{~h}$ at $2000 \mathrm{~V}$ on a $30 \mathrm{~cm} \times 40 \mathrm{~cm} \times$ $0.4 \mathrm{~mm} \mathrm{20 \%}$ (19:1 mono:bis) denaturing gel in the presence of a $100 \mathrm{mM}$ Tris-borate, $2.5 \mathrm{mM}$ EDTA buffer; $\mathrm{pH}$ 8.3. Products were visualised by phosphorimaging. The amount of radioactivity in the bands corresponding to the products of enzymatic reactions was determined by using the imaging device Cyclone ${ }^{\circledR}$ and the Optiquant image analysis software (PerkinElmer).

\section{Acknowledgements}

This work was financially supported by a grant from K. U. Leuven (GOA). We would like to thank Prof. Jef Rozenski for providing HRMS, Luc Baudemprez for recording the NMR spectra, and Chantal Biernaux for editorial help.

\section{Authors' contributions}

$\mathrm{PH}$ conceived the research project, XPS carried out the experiments (excep the stability studies), MM performed the stability studies. PH and XPS have written the manuscript. All authors read and approved the final manuscript.

\section{Competing interests}

The authors declare that they have no competing interests.

Received: 9 August 2011 Accepted: 4 October 2011

Published: 4 October 2011

\section{References}

1. Neuman MW, Neuman WF, Lane K: On the possible role of crystals in the origins of life. 3. The phosphorylation of adenosine to AMP by apatite. Curr Mod Biol 1970, 3:253-259.

2. Neuman MW, Neuman WF, Lane K: On the possible role of crystals in the origins of life. IV. The phosphorylation of nucleotides. Curr Mod Biol 1970, 3:277-283.

3. Lohrmann R, Orgel LE: Urea-inorganic phosphate mixtures as prebiotic phosphorylating agents. Science 1971, 171:490-494.

4. Bishop MJ, Lohrmann R, Orgel LE: Prebiotic phosphorylation of thymidine at 65 degrees $C$ in simulated desert conditions. Nature 1972, 237:162-164.

5. Handschuh GJ, Orgel LE: Struvite and prebiotic phosphorylation. Science 1973, 179:483-484

6. Ferraris DV: Evolution of poly(ADP-ribose) polymerase-1 (PARP-1) inhibitors. From concept to clinic. J Med Chem 2010, 53:4561-4584.

7. Lehman IR: DNA Ligase: Structure, Mechanism, and Function. Science 1974, 186:790-797.

8. Sawai H: Divalent metal ion-mediated phosphodiester bond formation from adenosine-5'-phosphorimidazolide with glycolic acid or lactic acid in aqueous solution. A nonenzymatic model reaction for nucleotidyl transfer. Bull Chem Soc Jap 1990, 63:692-696.

9. Adelfinskaya O, Herdewijn P: Amino acid phosphoramidate nucleotides as alternative substrates for HIV-1 reverse transcriptase. Angew Chem Int Ed 2007, 46:4356-4358.

10. Adelfinskaya $O$, Terrazas $M$, Froeyen $M$, Marlière $P$, Nauwelaerts $K$ Herdewijn P: Polymerase-catalyzed synthesis of DNA from phosphoramidate conjugates of deoxynucleotides and amino acids. NuCl Acids Res 2007, 35:5060-5072.

11. Terrazas M, Marlière $P$, Herdewijn $P$ : Enzymatically catalyzed DNA synthesis using L-Asp-dGMP, L-Asp-dCMP, and L-Asp-dTMP. Chem Biodiversity 2008, 5:31-39.

12. Giraut A, Dyubankova N, Song X-P, Herdewijn P: Phosphodiester Substrates for incorporation of nucleotides in DNA using HIV-1 Reverse Transcriptase. ChemBioChem 2009, 10:2246-2252.
13. Zlatev I, Giraut A, Morvan F, Herdewijn P, Vasseur J-J: $\delta$-Di-carboxybutyl phosphoramidate of 2'-deoxycytidine-5'-monophosphate as substrate for DNA polymerization by HIV-1 reverse transcriptase. Bioorg Med Chem 2009, 17:7008-7014.

14. Yang $S$, Froeyen $M$, Lescrinier $E$, Marlière $P$, Herdewijn $P$ : 3-Phosphono-Lalanine as pyrophosphate mimic for DNA synthesis using HIV-1 reverse transcriptase. Org Biomol Chem 2011, 9:111-119.

15. Giraut $A$, Herdewijn P: Influence of the linkage between leaving group and nucleoside on incorporation efficiency in DNA catalyzed by reverse transcriptase. ChemBioChem 2010, 11:1399-1403.

16. Song X-P, Bouillon C, Lescrinier $E_{1}$ Herdewijn P: Iminodipropionic acid: a better leaving group for DNA polymerization by HIV-1 reverse transcriptase. ChemBioChem 2011, 12(12):1868-80.

17. Lohrmann $\mathrm{R}$, Orgel LE: Preferential formation of $\left(2^{\prime}-5^{\prime}\right)$-linked internucleotide bonds in non-enzymatic reactions. Tetrahedron 1978, 34:853-855.

18. Bekenek K, Abbotts J, Wilson H, Kunkel TA: Error-prone polymerization by HIV-1 reverse transcriptase. Contribution of template-primer misalignment, miscoding, and termination probability to mutational hot spots. J Biol Chem 1993, 268:10324-10334.

19. Kool ET: Active site tighness and substrate fit in DNA replication. Annu Rev Biochem 2002, 71:191-219.

20. Gardner FA, Jack WE: Acyclic and dideoxy terminator preferences denotes divergent sugar recognition by archaeon and Taq DNA polymerases. Nucl Acids Res 2002, 30:605-613.

21. Creighton S, Bloom LB, Goodman MF: Gel fidelity assay measuring nucleotide misinsertion, exonucleoolytic proofreading, and lesion bypass efficiencies. Methods Enzymol 1995, 262:232-256.

22. Creighton S, Goodman MF: Gel kinetic analysis of DNA polymerase of fidelity in the presence of proofreading using backteriophage T4 DNA polymerase. J Biol Chem 1995, 270:4759-4774.

23. von Kiedrowski G: A Self-Replicating Hexadeoxynucleotide. Angew Chem Int Ed 1986, 25:932-935.

doi:10.1186/1759-2208-2-3

Cite this article as: Song et al:: Enzymatic synthesis of DNA employing pyrophosphate-linked dinucleotide substrates. Journal of Systems Chemistry 2011 2:3.

\section{Publish with ChemistryCentral and every scientist can read your work free of charge \\ "Open access provides opportunities to our colleagues in other parts of the globe, by allowing anyone to view the content free of charge." W. Jeffery Hurst, The Hershey Company. \\ - available free of charge to the entire scientific community \\ - peer reviewed and published immediately upon acceptance \\ - cited in PubMed and archived on PubMed Central \\ - yours - you keep the copyright \\ Submit your manuscript here: \\ http://www.chemistrycentral.com/manuscript/<smiles>c1ccccc1</smiles> ChemistryCentral}

